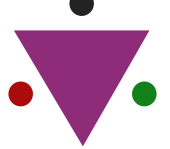

IJCRR

Section: Healthcare

Sci. Journal Impact

Factor: 6.1 (2018)

ICV: 90.90 (2018)

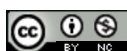

Copyright@IJCRR

\section{Pharmaceutico-Analytical Standardization and In Vivo Evaluation of Acute Toxicity, Genotoxicity, Anti-Genotoxic Effect and Spermatogenic Action of Musalyadi Churna}

\author{
Mujahid B. Khan ${ }^{1}$, Bharat Rathi², Shital Telrandhe ${ }^{3}$, Amoli Belsare ${ }^{4}$ \\ 'Assistant Professor, Department of Rasashastra \& Bhaishajya Kalpana, Assistant Professor, Mahatma Gandhi Ayurved Medical College, \\ Hospital and Research centre Salod (H), Datta Meghe lnstitute of Medical Sciences,(Deemed to be University), Sawangi (M) Wardha, \\ Maharashtra, India; 'Department of Rasashastra \& Bhaishajya Kalpana, Professor, Mahatma Gandhi Ayurved Medical College, Hospital and \\ Research centre Salod (H), Datta Meghe Institute of Medical Sciences,(Deemed to be University), Sawangi (M)Wardha, Maharashtra, India; \\ ${ }^{3}$ Research Consultant, Jawaharlal Nehru Medical College, Datta Meghe Institute of Medical Sciences, Nagpur, India; 4 Professor, Electronics \& \\ Tele. Engineering, Yeshwantrao Chavan College of Engineering, Nagpur, India.
}

\title{
ABSTRACT
}

Introduction: Infertility is a major reproductive health problem today in which Male infertility may be contributory to 30 to $40 \%$ of infertile couples. Musalyadi Churna is most commonly utilized classical Ayurvedic formulation in the management of impotency and infertility which are a major increasingly worldwide concern. It is a combination of herbal drugs like Musali (Chloro-phytum borivilianum), Vidarikanda (Pueraria tuberosa DC), Guduchi Tinospora cordifolia (Willd Miers ex Hook. f. and Thoms.), Kapikacchu (Mucunna prurita Hook.), Gokshura (Tribulus Terrestris Linn.), Shalmali (Bambax malabaricum DC) and Amalaki(Phyllanthus Emblica Linn.).

Methods: Musalyadi Churna will be prepared as per the reference of classical text Sharangdhar Samhita for pharmaceutical study and then its analytical study will be done. In experimental studies To assess the toxicity of Musalaydi churna, its acute oral toxicity on Wistar/SD rats will be performed using OECD 423 guidelines; Genotoxicity and Antigenotoxicity will be performed using Chromosomal aberration assay on 36 Swiss albino mice and Spermatogenesis study will be conducted on 60 Wistar/SD male rats as per OECD guidelines and scientific research articles.

Expected Results: Observations of pharmaceutical and experimental studies will be noted and presented in the form of tables, chart, photographs etc.

Conclusion: As the ingredients of Musalyadi churna are easily available and the method of preparation does not require much time and manpower, therefore if this formulation showed significant efficacy then this will open a new gateway for the management of infertility.

Key Words: Musalyadi churna, Genotoxicity, Spermatogenesis, Infertility

\section{INTRODUCTION}

Ayurveda is a life science which given hope to the world for the management of impotency and infertility related diseases. Modern lifestyle has a critical role in developing a wide range of diseases among which diseases related to the reproductive system are one of the major concern. Infertility affects an estimated $15 \%$ of couples globally, amounting to 48.5 million couples. ${ }^{1,2}$ There are numerous formulations in Ayurveda which are mentioned to possess significant Vajikarana properties which are related to both aphrodisiac as well as sper- matogenic action. Many formulations which are available in the market and frequently utilized in treating impotency and infertility are either from the classical text of Ayurveda or derived from Vajikarana drugs mentioned in Ayurveda. Musalyadi Churna is one of such formulation which is mostly used by Ayurvedic physicians. ${ }^{3}$ It is a combination of Musali, Vidarikanda, Guduchi Satva, Kapikacchu, Gokshur Shalmali and Amalaki. However, there is a lack of scientific evidence related to Acute Toxicity, Genotoxicity, Anti-Genotoxic effect and Spermatogenic action of Musalyadi Churna. Moreover,

\section{Corresponding Author:}

Dr. Bharat Rathi, Professor, Department of Rasashastra and Bhaishajya Kalpana, Mahatma Gandhi Ayurved Medical College, Hospital and Research centre Salod (H), Datta Meghe Institute of Medical Sciences, (Deemed to be University), Sawangi (M) Wardha, Maharashtra, India. Email: bharatrathi174@gmail.com

ISSN: 2231-2196 (Print) ISSN: 0975-5241 (Online)

Received: $25.09 .2020 \quad$ Revised: 27.10 .2020

Accepted: 10.11 .2020

Published: 30.11 .2020 
the efficacy level of Musalyadi Churna is not known which is needed to understand its valuability in terms of cost-effectiveness and superiority/inferiority in comparison to standard drug. Thus present work will be able to fulfill these gaps of scientific evidence and if significant positive results obtained in this work then it will be a valuable contribution to the management of impotency and infertility.

\section{MATERIAL AND METHODS}

Study design -This is the pharmaceutical, analytical and experimental study. The study will be conducted at M.G.A.C.H.R.C., Salod (H), Central Animal House, DMIMS (DU), Wardha and other Lab of National Repute and as recognized or recommended by DMIMS (DU). Ethical approval has been got from Institutional Ethics committee (IEC) and the Institutional animal ethics committee (IAEC).

Present work will be conducted under the following headings;

a) Pharmaceutical study: This study is related to drug preparation in which three different batches of Musalyadi Churna will be prepared to establish pharmaceutical standardization. The pharmaceutical study will be done in the following steps (figure 1);

I) Procurement of Raw materials: All required raw materials will be procured from the field and authentic reliable source.

II) Authentication of Raw materials: Raw drugs will be verified and authenticated by Department of Dravya Guna of MGAC and RC. Raw drug will be standardized as per A.P.I.

III) Extraction of Guduchi Satva: ${ }^{4}$

गुडूचीं खणडश: कृत्वा कुट्टयत्विवा सुमरद्येत्।

वस्त्रेण वधितं तोयं स्त्रावयेत्तचछनै: शनै:।

शुध्दशड्खनभिं चूर्णमेतै: सम्मश्रियेद्भषिक्।

- Yogratnakar Rajyakshma Chikitsa

The procedure of Extraction of Guduchi Satva:

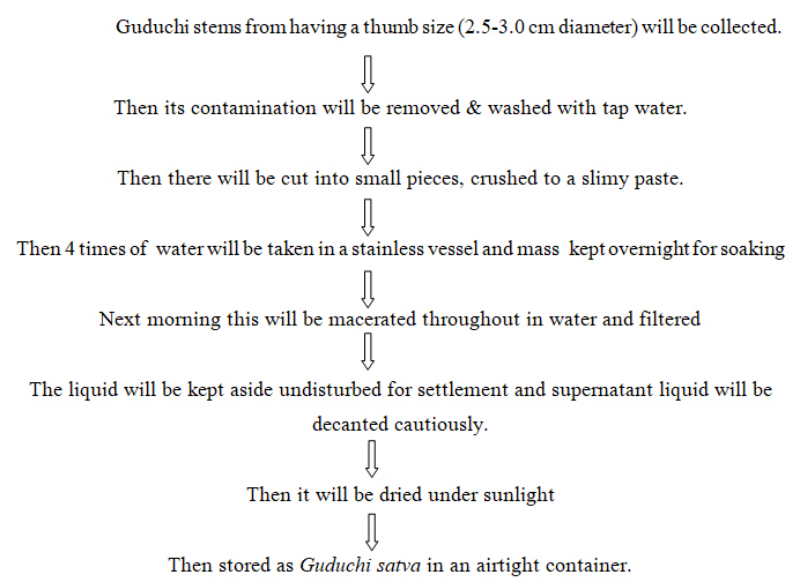

Figure 1: Flow diagram of the unit procedure of Extraction of
Guduchi Satva.

IV) The classical method of Preparation of Musalyadi Churna (Table 1): ${ }^{3}$

मुसलीकन्दचूर्णं तु गुडुचीसत्वसंयुतम।

वानरीगोकष्राभाभ्यां च शाल्मलीशर्करामलै: ॥

आलोड्य घृतदुग्र्धाभ्यां भक्षयेत्कामवृद्ध्ये ॥

Sharandhar Samhita Madhyam khanda 6/160

Table 1: Ingredients and quantity of Musalyadi Churna:

\begin{tabular}{llll} 
Sr. No. & Ingredients & Part Used & Quantity \\
\hline 1 & Musali & Rhizome & 1 Part \\
2 & Vidarikanda & Rhizome & 1 Part \\
3 & Guduchi Satva & Stem bark extract & ${ }_{1}$ Part \\
4 & Kapikacchu & Seed & 1 Part \\
5 & Gokshur & Fruit, Root & 1 Part \\
6 & Shalmali (Semal & Root & 1 Part \\
& Musali) & & \\
7 & Amala & Fruit & 1 Part \\
8 & Khanda Sharkara & - & 1 Part \\
\hline
\end{tabular}

The procedure of preparation of Musalyadi churna (figure 2):

All the procured and authenticated drugs will be dried in shade.<smiles>[CH]</smiles>

All the drugs will be cleaned to remove foreign matter

凸

The individual drugs will be powdered using a pulverizer.

几

The individual drugs will be sieved through mesh no. 80 .

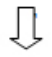

he required quantity of drugs (powder) will be weighed separately.

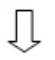

All the powders will be mixed by the mass mixture.

几

The mixed formulation will be unloaded and weighed.

ఏ

It will be stored in an airtight container

Figure 2: Flow diagram of the unit procedure of preparation of Musalyadi churna:

\section{b) ANALYTICAL STUDY:}

For analytical study description (organoleptic parameters) and physicochemical parameters like Acid insoluble ash, Total ash, Water-soluble extractive, pH, HPTLC, Loss on drying at $105^{\circ} \mathrm{c}, \mathrm{GCP}$, Particle size, Microbial contamination, Pesticide residue will be done. 


\section{c) EXPERIMENTAL STUDY:}

The experimental study is divided into three parts i.e Acute oral Toxicity, Chromosomal Aberration Assay and Spermatogenesis study of Musalyadi churna. These study will be conducted as per OECD guidelines and Scientific research articles.

The animal will be acclimatized for 14 days prior beginning of the study. They will be housed at a relative humidity (55 $\pm 5 \%), 12 \mathrm{~h} / 12 \mathrm{~h}$ light-dark cycle, ambient temperature (22 $\pm 1^{\circ} \mathrm{C}$ ). Animals will be fed with Amrit brand of food and distilled water ad libitum.

\section{Study design and Experimental procedures:}

\section{1] Acute oral Toxicity:}

Three female rats will be used for acute oral toxicity study according to OECD (Organization for Economic Coopera- tion Development) guidelines 423. The study will involve approximately 12 animals. They will be dosed at $2000 \mathrm{mg}$ /Kg body weight. Rats will be administered the test material suspended in suitable vehicle i.e Cows Milk and Cows butter. The animals will be deprived of feed 4 hours before dosing and 2 hours after dosing. Water will be allowed ad libitum. All the animals will be observed for 14 days after dosing. During the first 30 minutes after dosing, animals will be observed individually at least once and periodically during the first 24 hours and once daily thereafter, for a total of 14 days. Then signs of ill health, behavioural changes etc will be recorded for individual animals (table 2).

The body weights will be recorded on test day 1 (pre-administration fasting weight) and days 7 and 14 post-treatment or at death and then after necropsy pathological study will be done. ${ }^{5}$

\section{2] Genotoxicity and Anti-Genotoxicity study in Mice}

\section{Table 2: Grouping for Genotoxicity and Anti-Genotoxicity study}

The mice will be divided into the following groups:

\begin{tabular}{lll} 
Groups & Drug & No. of animals \\
Group I (Normal Control) & - & 6 \\
Group II (Vehicle control) & Godugdha, Goghrita & 6 \\
Group III (Positive control) & N-Nitroso-N-methylurea (NMU)/ & 6 \\
& Cyclophosphamide(CYP) Single-dose administration & 6 \\
Group IV (Test group) & and cell harvesting after 24 hrs. & 6 \\
Group V(Pre-treatment) & Mice will be given first Musalyadi Churna and then & 6 \\
Group V(Post-treatment) & NMU/CYP. & \\
& Mice will be given first NMU/CYP and then Musalyadi & \\
\hline
\end{tabular}

For this study, chromosomal aberration assay will be followed. Mice will be dosed with respective treatments and then the animals will be sacrificed by cervical dislocations and bone marrow cells will be harvested. Then Colchicine will be administered intraperitoneally and slides will be prepared. The harvested cells will be incubated at $37^{\circ} \mathrm{C}$ and then centrifuged at $1000 \mathrm{rpm}$. A total of 100 well-spread metaphase plates will be scored for chromosomal aberrations at a magnification of $1000 \mathrm{X}(100 \mathrm{X} 10)$ for each group. Then different types of chromosomal aberration will be scored. Then statistical significance will be determined..$^{6,7}$

\section{3] Spermatogenesis Study of Musalyadi churna in Male Rats}

Table 3: Grouping for Spermatogenesis Study of Musalyadi churna in Male Rats

The rats will be divided as follows:

$\begin{array}{llllll}\text { Groups } & \text { Drug } & \text { Dose } & \text { No. } & \text { Duration } & \text { Route } \\ \begin{array}{l}\text { Group I } \\ \text { (Normal }\end{array} & - & - & 6 \text { Rats } & 70 \text { days } & - \\ \text { Control) } & & & & & \\ \begin{array}{l}\text { Group II } \\ \text { (Disease }\end{array} & \text { Nicotine } & 0.6 \mathrm{mg} / & 6 \text { Rats } & 70 \text { days } & \text { Oral } \\ \text { control) } & & \mathrm{kg} & & & \\ \begin{array}{l}\text { Group III } \\ \text { Vehicle Goghrita, } \\ \text { Control) }\end{array} & \text { Godugdha } & \text { b.wt } & & & \\ & & & & & \\ \end{array}$




\begin{tabular}{|c|c|c|c|c|c|}
\hline $\begin{array}{l}\text { Group IV } \\
\text { (Stand- } \\
\text { ard drug) }\end{array}$ & $\begin{array}{l}\text { Nicotine+ } \\
\text { Clomifen } \\
\text { citrate }\end{array}$ & $\begin{array}{l}\text { o.6 mg/ } \\
\text { kg b.wt }\end{array}$ & 6 Rats & 70 days & Oral \\
\hline $\begin{array}{l}\text { Group } \\
\text { V (Test } \\
\text { dose I) }\end{array}$ & $\begin{array}{l}\text { Nicotine + } \\
\text { Musalyadi } \\
\text { Churna }\end{array}$ & $\begin{array}{l}\text { o.6mg/ } \\
\text { kg+ } \\
\text { (6 gm - } \\
\text { human } \\
\text { dose) }\end{array}$ & 6 Rats & 70 days & Oral \\
\hline $\begin{array}{l}\text { Group } \\
\text { VI (Test } \\
\text { dose-II) }\end{array}$ & $\begin{array}{l}\text { Nicotine + } \\
\text { Musalyadi } \\
\text { Churna }\end{array}$ & $\begin{array}{l}\text { o.6mg/ } \\
\text { kg+ } \\
\text { (9 gm - } \\
\text { human } \\
\text { dose) }\end{array}$ & 6 Rats & 70 days & Oral \\
\hline $\begin{array}{l}\text { Group } \\
\text { VII } \\
\text { (Test } \\
\text { dose-III) }\end{array}$ & $\begin{array}{l}\text { Nicotine + } \\
\text { Musalyadi } \\
\text { Churna }\end{array}$ & $\begin{array}{l}\text { o.6mg/ } \\
\text { kg+ } \\
\text { (12 gm - } \\
\text { human } \\
\text { dose) }\end{array}$ & 6 Rats & 70 days & Oral \\
\hline $\begin{array}{l}\text { Group } \\
\text { VIII } \\
\text { (Only } \\
\text { Test } \\
\text { dose) }\end{array}$ & $\begin{array}{l}\text { Musalyadi } \\
\text { Churna }\end{array}$ & $\begin{array}{l}\text { (6 gm - } \\
\text { human } \\
\text { dose) }\end{array}$ & 6 Rats & 70 days & Oral \\
\hline $\begin{array}{l}\text { Group IX } \\
\text { (Only } \\
\text { Test } \\
\text { dose) }\end{array}$ & $\begin{array}{l}\text { Musalyadi } \\
\text { Churna }\end{array}$ & $\begin{array}{l}\text { (9 gm - } \\
\text { human } \\
\text { dose) }\end{array}$ & 6 Rats & 70 days & Oral \\
\hline $\begin{array}{l}\text { Group X } \\
\text { (Only } \\
\text { Test } \\
\text { dose) }\end{array}$ & $\begin{array}{l}\text { Musalyadi } \\
\text { Churna }\end{array}$ & $\begin{array}{l}\text { (12 gm - } \\
\text { human } \\
\text { dose) }\end{array}$ & 6 Rats & 70 days & Oral \\
\hline
\end{tabular}

Rats will be fed with rat feed and water ad libitum. Nicotine 99\% will be dissolved in physiological saline and will be given orally by gastric tube for 70 days. The same volume of saline will receive by control Rats (Table 3 ).

On the 71st day, animals will be allowed to fast for overnight and will be subjected to euthanasia. Tissues will be collected in ice-cold containers for various biochemical estimations like Nicotine, Serum Cholesterol, ALP Tissue, Tissue Acid Phosphatase, ALP Serum, Total Protein and also epididymal Sperm Count and Sperm Morphology also seen. ${ }^{8,9}$

\section{Animals required}

a. Species/Common name: Wistar/ SD Rats and Swiss Albino mice

b. Age / weight / size: 180-200gms for rats and 20-25 gms for mice

c. Gender: Both

d. Sample Size: Number to be used 12 rats For Acute Toxicity study approx. 12 female rats will be used. For Spermatogenesis study 60 male rats and for Genotoxicity study 36 mice of both sexes will be used.

e. Number of days each animal will be housed: Approx 3 months f. Proposed source of animals: Central Animal House, DMIMS (DU), Wardha

g. The rationale for animal usage: Animal usage is necessary for this study to determine the safety, spermatogenic potential and antigenotoxic effect of Musalyadi churna.

h. Estimated number of animals essential because minimum of 6 animals per group are required for statistical significance.

Dose: The dose for the experimental is calculated as per clinical human dose of Musalyadi churna (12000 mg per day) to an animal dose based conversion factor of FDA guidelines. Dose route is oral for all the studies.

Formula $=$ Human dose $/ 60 \times$ body surface area ratio convertibility factor.

\section{DATA ANALYSIS}

Unpaired t-test and One way ANOVA will be applied to get the results of the study.

\section{EXPECTED OBSERVATION}

Observations will be noted and presented in the form of tables, chart, photographs etc. Musalyadi churna is a combination of herbal ingredients hence it is predicted that this formulation will found non-toxic in Acute Oral toxicity test. Musalyadi churna will have significant spermatogenic action as well as it possesses genoprotective efficacy and it does not have any genotoxicity.

\section{DISCUSSION}

Plants derived medicines have played a major role in health care of ancient and modern cultures. ${ }^{10}$ However according to modern science, each drug needs to be scientifical, pre-clinically and clinically evaluated for the global acceptance. ${ }^{11}$ In the medical field, the analytical studies of Ayurvedic formulations help to form the base for standardization. ${ }^{12}$ Standardization of Ayurvedic medicines on pharmaceutical and analytical level is the most important aspect before beginning research on pre-clinical and clinical ground. Musalyadi churna is a herbal formulation primarily indicated for diseases of the male reproductive system. It will be prepared as per ingredients and proportion mentioned in Table 1 and as per reference of Sharangdhar Samhita. Genotoxicity and Antigenotoxicity studies will be performed as per the groups mentioned in Table 2. All drugs which have targeted action on the human reproductive system is needed to be tested for their genotoxicity profile as even a small change in the genome may result in significant abnormality in offspring. The anti-genotoxic study provides information on the efficacy of 
drugs against preventing the hazardous effect of chemicals on chromosomes. Spermatogenesis study will be performed as per the grouping mentioned in Table 3. Spermatogenesis studies are the key to know whether a drug stimulate sperm production, sperm motility and content of seminal fluid which are considerable factors of fertilization mechanism.

Animal studies give us the guidelines and help us to solve the queries on the extent of the use of medicine in regards to its safety margins. The individual drugs of this formulation have proven their beneficial effect in impotency and infertility. ${ }^{13-25}$ Studies related to oligospermia was reported by Varma et al. ${ }^{26}$ Other toxicity related studies were reported. ${ }^{27,28} \mathrm{How}-$ ever there is no established scientific evidence related to the range of combined effect of these ingredients in the form of Musalyadi Churna. Moreover, this formulation has target action on the reproductive system and thus its genotoxic profile need to be established and this impediment will be solved by present work.

\section{Strength and limitations}

To the best of our knowledge, there is no work done until today on this topic. This study will provide spermatogenesis effect of Musalyadi Churna on Rodents with genontoxicity profile. This study is limited to animal experiment which has few constraints while applying obtained results in human being. This represents that animal experiments have their importance but clinical studies are needed for finalization of the efficacy of any drug.

\section{CONCLUSION}

Available formulations on infertility are too much costly and their ADR, as well as lack of genoprotective evidence, is a matter of concern. The present study is an attempt to discover a new cost-effective spermatogenic formulation with establishing its evidence related to genoprotective action with spermatogenesis profile. As the ingredients of Musalyadi churna are easily available and the method of preparation does not require much time and manpower, therefore if this formulation showed significant efficacy then this will open a new gateway for the management of infertility.

\section{Availability of data and materials - Nil}

Consent for publication - Not applicable

Competing interests - Authors don't have any competing interest.

\section{ACKNOWLEDGMENT}

Authors acknowledge the immense help received from the scholars whose articles are cited and included in references to this manuscript. The authors are also grateful to authors / editors / publishers of all those articles, journals, and books from which the literature for this article has been reviewed and discussed.

\section{Conflict of Interest: Nil}

Source of Funding: Nil

\section{REFERENCES}

1. Mehta RH, Makwana H, Ranga GM, Srinivasan RJ, Virk SS. Prevalences of oligozoospermia and azoospermia in male partners of infertile couples from different parts of India. Asian J Androl 2006; 8 (1): 89-93

2. Kumar N, Choudhari AR, Singh AK. Prevalence of male factor infertility in the last ten years at a rural tertiary care centre of central India: a retrospective analysis. Indian J Obstet Gynaecol Res 2015;2(3):132-6.

3. Tripathi B. Sharangdhar Samhita, Madhyam khanda 6/160, Choukhambha Surbharti Prakashan, Varanasi, Edition- 2012;193

4. Shastry LY. Rajyakshma Chikitsa Adhyaya, Choukhambha Prakashan, Varanasi, Reprint edition, 2010; 366

5. Oral OA. Toxic Class Method. Guideline No. 423, Adopted 23.03. 1996. Eleventh Addendum to the OECD Guidelines for the Testing of Chemicals. Organisation for Economic Co-operation and Development, Paris: OECD. 2000.

6. Thybaud V, Lorge E, Levy DD, van Benthem J, Douglas GR, Marchetti F, Moore MM, Schoeny R. Main issues addressed in the 2014-2015 revisions to the OECD genetic toxicology test guidelines. Environ Mol Mutagene 2017 Jun;58(5):284-95.

7. OECD. OECD Guidelines for the Testing of Chemicals-Test Guideline 475, Mammalian Bone Marrow Chromosome Aberration Test (adopted 21 July, 1997).

8. Wyrobek AJ, Bruce WR. Chemical induction of sperm abnormalities in mice. PNAS 1975;72(11):4425-9.

9. Filler R. Methods for evaluation of rat epididymal sperm morphology. Methods in Toxicology. 1993;3:334-43.

10. Khan MB, Sathe N. Advanced protocols for in-vivo evaluation of herbal anticancer drugs: A Review. J Indian Syst Med 2018;6(4):195.

11. Chavan R, Khan M, Sathe N, Mankar NA. A Review: SRB Assay for Screening Anticancer Activity of Herbal drugs (in-Vitro). Int Ayu Med J 2016;4(2):66-70.

12. Rathi B, Rajput D, Wanjari A, Khan M, Rathi R. Physico-Chemical Analysis of Purana Ghrita (Old Clarified Butter) with special reference to Fatty Acid Profile. J Ind Syst Med 2018;6(1):4.

13. Kenjale R, Shah R, Sathaye S. Effects of Chlorophytum borivilianum on sexual behaviour and sperm count in male rats. Phytother Res 2008 Jun;22(6):796-801.

14. Ray S, Chatterjee K, De D, Ghosh D. Bioefficacy of hydromethanolic extract of the tuber of C hlorophytum borivilianum (Safed Musli) for the management of male infertility in cyproterone acetate-treated albino rats. Andrologia 2014 Aug;46(6):659-71.

15. Khan MB, Rathi BJ, Rajput D, Wanjari A. A review on classical Vajikarana formulations of Shweta Musali. J Indian Syst Med 2019 Oct;7(4):205.

16. Chauhan NS, Sharma V, Thakur M, Christine Helena Frankland Sawaya A, Dixit VK. Pueraria tuberosa DC extract improves androgenesis and sexual behaviour via FSH LH cascade. Scient World J 2013 Jan;2013.

17. Panares KA, Abamo F, Billacura M. Genotoxic, anti-genotoxic and protective evaluation of Tinospora cordifolia stem by 
peripheral blood micronucleus assay. Sci Int 2017;29:97-101.

18. Jayaganthan P, Perumal P, Balamurugan TC, Verma RP, Singh LP, Pattanaik AK, et al. Effects of Tinospora cordifolia supplementation on semen quality and hormonal profile in rams. Anim Reprodu Sci 2013;140(1-2):47-53.

19. Shukla KK, Mahdi AA, Ahmad MK, Shankhwar SN, Rajender S, Jaiswar SP. Mucuna pruriens improves male fertility by its action on the hypothalamus-pituitary-gonadal axis. Fertility Sterility 2009;92(6):1934-40.

20. Shukla KK, Mahdi AA, Ahmad MK, Jaiswar SP, Shankwar SN, Tiwari SC. Mucuna pruriens reduces stress and improves the quality of semen in infertile men. Evid Based Complement Alternat Med. 2010 Mar; 7(1): 137-144.

21. Sanagoo S, Oskouei BS, Abdollahi NG, Salehi-Pourmehr H, Hazhir N, Farshbaf-Khalili A. Effect of Tribulus Terrestris L. on sperm parameters in men with idiopathic infertility: A systematic review. Complement Ther Med 2019 Feb 1;42:95-103.

22. Bhargava C, Thakur M, Yadav SK. Effect of Bombax ceiba L. on spermatogenesis, sexual behaviour and erectile function in male rats. Andrologia 2012 May;44:474-8.
23. Antil V, Sinha BN, Pandey A, Diwan A, Saini P. Bombax malabaricum Dc: A salutary boon. Int J Pharma Innov 2013;3(2):1728.

24. Thakur SB, Rao MV. In vitro fluoride induced genotoxic effect on human blood lymphocyte cells and its amelioration by Emblica officinalis extract. Mol Cytogenet 2014 Jan;7(S1): P48.

25. Rao K, Devi KR. The Protective Effects of Phyllanthus Emblica in Cyclophosphamide Induced Genotoxicity in Mice. Int J Pure App Biosci 2016;4(5):90-7.

26. Varma A, Verma N, Acharya N, Nadkarni A. Study of Karyotyping and Y Chromosome Microdeletionscreening in Infertile Males with Azoospermia and Oligozoospermia Before Art. Int J Cur Res Rev| Vol. 2020 Aug;12(16):84.

27. Wadnerwar N, Patkar A. Chronic toxicity evaluation of Ayurvedic arsenical formulation Rasamanikya with special reference to heavy metal toxicity. Int J Pharma Res 2020;12(1):889-98.

28. Dafal A, Acharya S, Vidiyala H, Shukla S. Mycophenolate mofetil induced hepatotoxicityin a case of myasthenia gravis. J Datta Meghe Inst Med Sci Uni 2019;14(3):281. 